\title{
Factors Affecting Customer Brand Preference toward Electric Vehicle in Bangkok, Thailand
}

\author{
Rawin VONGURAI ${ }^{1}$
}

Received: May 31, 2020 Revised: June 14, 2020 Accepted: July 03, 2020

\begin{abstract}
The purpose of this research is to identify factors affecting consumer's brand preference toward environment-friendly products like electric vehicles in Bangkok, Thailand. The researcher conducted the study based on a quantitative approach and adapted a nonprobability sampling as a convenience sampling method. The data were collected from 400 respondents living in Bangkok, who are 18 years old and above, with significant knowledge of electric vehicles. This study adapted the Structural Equation Model (SEM) and Confirmatory Factor Analysis (CFA) to examine the model accuracy, reliability and verification influence of various variables. The results revealed that social influence has significant effect on environment concern as well as a positive effect on attitude. The initial significance of environment concern leads to a positive effect on fuel efficiency, followed by brand preference. Lastly, attitude has a significant effect on brand preference as attitude of consumers toward environment-friendly products affects the encouragement of brand preference, which largely depends on individual opinion. From an environmental concern, the researchers identified fuel efficiency and attitude having a positive and significant effect on brand preference toward environment-friendly products for electric vehicles. The authors also found that environmental concern and social influences on green purchasing behavior were significantly interrelated.
\end{abstract}

Keywords: Brand Preference, Social Influence, Environment Concern, Environment-friendly Product, Fuel Efficiency

JEL Classification Code: M10, M31, O32

\section{Introduction}

In 2050, globalization will affect the world demand for oil and it could increase dramatically along with the number of cars on the road, which will grow to 1.5 billion from 750 million in 2010 (Dnishev \& Alzhanova, 2016). The core reason is the rising population of cars in China and India, which are countries with a big purchasing power. So, it proves to be a good sign for the automobile industry and related trade as well as a bad sign for air quality because car usage produces a set of negative factors (Parry, Walls, \& Harrington., 2007). At the local level, air pollution has a

${ }^{1}$ First Author and Corresponding Author. Program Director, Innovative Technology Management, Graduate School of Business, Assumption University, Thailand [Postal Address: 592/3 Soi Ramkhamhaeng 24, Khwaeng Hua Mak, Khet Bang Kapi, Bangkok, 10240, Thailand] Email: rawinvng@au.edu

(c) Copyright: The Author(s)

This is an Open Access article distributed under the terms of the Creative Commons Attribution Non-Commercial License (http://Creativecommons.org/licenses/by-nc/4.0/) which permits unrestricted noncommercial use, distribution, and reproduction in any medium, provided the original work is properly cited. negative effect on people's health. (Hoek et al., 2013). As for the global impact, greenhouse gas emissions (GHG) from transportation is directly causing global warming or climate change (Lorenzoni \& Pidgeon, 2006; Woodcock et al., 2009). According to much research, diesel cars emit more pollution than regular gasoline cars. But there are better options because cars that use electricity are low-carbon although higher emissions in production and emissions from the electricity production process. Therefore, the necessity and acceleration for the vehicle emission reduction worldwide is generally accepted (UNFCCC, 2015) and switching to the use of electric vehicles is one of the core reasons.

Meanwhile in Thailand, there has been a great deal of research which proved that electric vehicle technology is capable of reducing $4.51 \%$ of energy usage in transportation by 2030 (energy consumption in transportation sector accounts as many as about 40,000 Kilo tons of oil equivalent) and from road transport in Thailand in 2008, it contributed to $14 \%$ of GHG emissions (the volume of the road transport sector reaches 50 million tons of carbon dioxide, equivalent to GHG emissions) (Energy Policy and Planning Office, 2016; International Transport Forum, 2010). 
International car manufacturers such as Nissan and $\mathrm{MG}$ are now promoting electric vehicles $(\mathrm{EV})$ in the local market to make Thailand the production hub of EVs in ASEAN. These car manufacturers claimed that their vehicles have intelligent mobility, but safe and friendly toward the environment, which means that they try to use certain factors of brand preferences to attract the attention of Thai consumers (Dao \& Nguyen, 2020). Theoretically, there are many factors that directly and indirectly influence brand preference, including environmental concern, social influence, attitude, and fuel efficiency (Gaur \& Kumar, 2018).

Unfortunately, based on statistical data from the Department of Land Transport of Thailand in 2017, only 80,000 hybrid electric vehicles, including plug-in hybrid electric vehicles, have been registered. In other words, the prevalence of electric vehicles in Thailand remains low despite being launched in 2009. Generally, consumers purchase automotive according to their preferred brands. Consequently, this research aims to identify factors that directly or indirectly affecting brand preference.

\section{Literature Review and Research Framework}

\subsection{Literature Review}

\subsubsection{Brand Preference}

Brand preference refers to the extent to which customers chose services provided by any particular company against other companies (Hellier, Geursen, Carr, \& Rickard, 2003). It reflects the loyalty toward a brand that they prefer. However, consumers will create more preferences for brands when their familiarity with a brand is increased and may affect their purchasing decision (Heilman, Bowman, \& Wright, 2000); cultural, social, personal and psychological factors are also at play. These factors should be combined to understand the role of each of them in developing brand preference (Ebrahim, Ghoneim, Irani, \& Fan, 2016). Therefore, it can be posited that psychological, environmental and social factors are important in terms of brand preference.

\subsubsection{Social Influence}

The influence of society has been identified through many studies. Generally, it is known as "person's perception" such as friends, family, colleagues and social groups who play an important role that affects individuals' attitudes and intentions toward a certain behavior (Rivis \& Sheeran, 2003; Hsu \& Lu, 2004). Social influence is the process of changing feelings and actions that can occur unconsciously or indirectly, where the majority can influence the minority (Rashotte, 2007). From the context of purchasing a car, the influences of a specific attitude from a large social group will affect individuals. It means that people will decide to purchase a vehicle influenced through socialization (Bartikowski \& Walsh, 2014), which was also revealed in the research conducted by Dagher and Itani (2012). Social influencing and environmental concern on green purchasing behavior were also found to be important interrelated factors. The purpose of this research is to identify whether social influence has a significant effect on environmental concern. Thus, the following hypotheses are proposed.

\section{$\boldsymbol{H}_{\boldsymbol{1}}:$ Social influence significantly affects environmental} concern.

$\boldsymbol{H}_{2}:$ Social influence significantly affects attitude towards environment-friendly products.

\subsubsection{Environmental Concern}

The issues related to the environment are gaining importance in recent years. However, personal ethics on protecting the environment fluctuates with awareness and social influence, which is a prevailing social practice. It is realized that higher environmental concerns lead to a tendency to choose environmental-friendly products as well as brands (Junior et al., 2014), due to an increase in information and knowledge of environmental issues and green products. So, consumers are beginning to search for green products and that will contribute to the consumption of green products. Moreover, environmentally-conscious consumers tend to look at the features of the products that are involved with the environment before forming preferences (Kwon, Engils, \& Mann, 2016). For example, the main features of a vehicle that consumers are interested in, should offer environment-friendly products and fuel efficiency. Therefore, the environmental concern of consumers tends to be related to fuel efficiency of any particular car. Based on the above discussion, the following hypotheses are developed.

\section{$\boldsymbol{H}_{3}:$ Environmental concern significantly affects fuel efficiency. \\ $\boldsymbol{H}_{4}:$ Environmental concern significantly affects brand preference.}

\subsubsection{Fuel Efficiency}

Several studies have analyzed fuel efficiency as an important factor influencing consumer preferences (Hensher, Greene, \& Li., 2011; Tay \& McCarthy, 1991, 1998; Train $\&$ Winston, 2007). Furthermore, the researchers identified that these product-related attributes had a positive effect on consumer brand preference (Cobb-Walgren, Ruble, \& Donthu, 1995; Myers, 2003; Park \& Srinivasan, 1994). However, the National Automobile Dealers Association 
identified fuel efficiency as one of the key factors that people consider when purchasing a vehicle (NADA, 2014). Hence, the following hypothesis is developed.

\section{$\boldsymbol{H}_{5}$ : Fuel efficiency significantly affects brand preference.}

\subsubsection{Attitude}

The attitude is derived from knowledge and understanding, which represent an individual's mind. It is contagious as people influence each other's attitudes by agreeing or conflicting through their responses and experiences. In addition, attitudes reflect an identified social group (Oh \& Park, 2020; Smith \& Hogg, 2008). Moreover, attitude refers to a "learned predisposition to respond in a consistently favorable or unfavorable manner with respect to a given object" (Fishbein \& Ajzen, 1975). In the context of vehicle purchasing, Hsu, Chang and Yansritakul (2017) defined attitude as an individual's positive or negative feelings of environmental-friendly vehicle products. Therefore, attitude has a significant impact on green products and is one of the most effective predictors of purchasing green products. Hence, the following hypothesis is derived.

$\boldsymbol{H}_{6}:$ Attitude towards environment-friendly products significantly affects brand preference.

\subsection{Research Framework}

The conceptual framework is developed from studying the theoretical frameworks related to this research. It is adapted from the theoretical model of 'Environmental concern: an issue for poor or rich' (Teoh \& Gaur, 2019), which aims to study and explore the direct and indirect effect of each variable on brand preference. This research examines social influence (SI), attitude (A), environmental concern (EC) and fuel efficiency (FE) that have an effect on brand preference (BP). The conceptual framework of this study is shown in Figure 1.

This study aims to study the factors affecting consumers' brand preference toward environment-friendly products like electric vehicle as regards various aspects such as social influence (SI), attitude (A), environmental concern (EC), fuel efficiency (FE) and brand preference (BP) in Bangkok, Thailand. In addition, the research investigates the causal relationship between each variable to unveil the influence of these factors affecting brand preference.

\section{Methodology}

For this study, the researcher used quantitative methods, improper sampling methods, and convenient sampling methods. The developed questionnaire was distributed offline and online to the target group of Thais living in Bangkok, aged 18 years old and above, with knowledge of electric cars because most of the EV charging stations are in Bangkok. Indeed, the majority of electric car users are in Bangkok. The data has been analyzed for factors that affect customer brand preference for the electric vehicle brand. The questionnaire consists of three parts. The first part includes screening questions to identify the respondents. Secondly, a 7-point Likert scale is used to measure five different variables, ranging from extreme disagreement (1) to strong agreement (7) for the analysis of all hypotheses. Finally, questions on demographic factors have been collected based

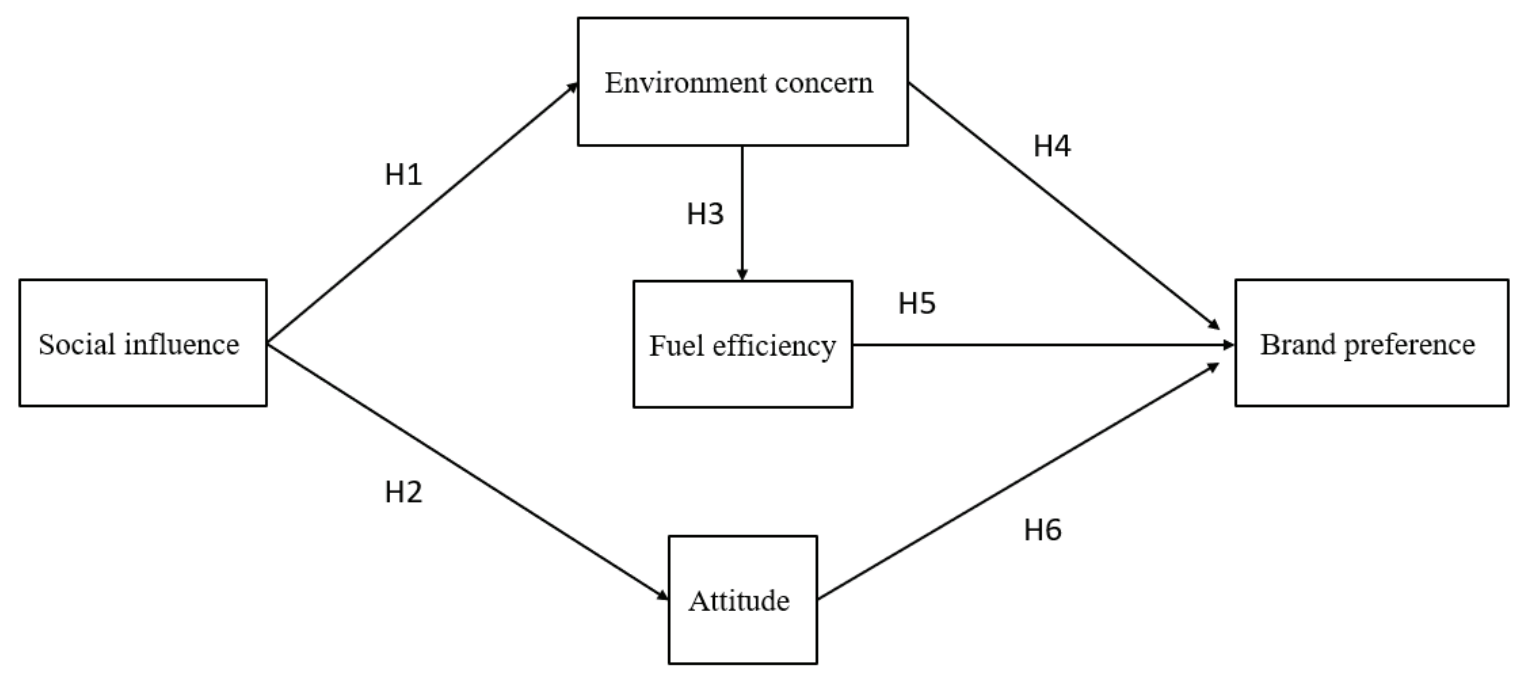

Figure 1: Conceptual Framework 
on respondent's gender, age, monthly income, occupation and the most preferred electric vehicle brand. For pilot testing, the questionnaire was given to 30 respondents. The researchers used Cronbach's Alpha method to verify the reliability test from the respondents. After the reliability test, the questionnaire was distributed to 400 target respondents. The researcher analyzed the data collected through SPSS 24 and AMOS 18.0. Afterwards, Confirmatory Factor Analysis (CFA) was conducted to test the convergence accuracy, and the validation results were classified. The measurement model fits the overall test with given data to ensure the accuracy and reliability of the model. Finally, the researcher used the Structural Equation Model (SEM) to examine the effect of variables.

\subsection{Population and Sample Size}

The population used in this research consists of Thais living in Bangkok, aged 18 years old and above, with knowledge of electric cars. Kline (2011) recommended that the appropriate minimum sample size of the Structural Equation Model (SEM) must be 200 respondents. The total number of respondents that participated in the survey were 432 from diverse background. After screening all the responses, 400 responses were considered eligible for further use in this study.

\subsection{Sampling Technique}

The questionnaires were distributed using a NonProbability Sampling Method of convenience sampling to gather data from 400 target respondents. The data were collected through both offline and online channels with an equal amount of questionnaire distribution. Via offline channel, the questionnaires were distributed to vehicle showrooms of various brands in Bangkok to reach 200 respondents who are interested in purchasing electric vehicle. Via online channel, the questionnaires were distributed randomly by using convenient access and proximity of researchers to reach 200 respondents via online data collection platforms and social media. Afterwards, the respondents will forward the questionnaires to their family members, colleagues or friends who met the necessary qualifications of the target group.

\subsection{Pilot Test}

Cronbach's Alpha analysis is used to test the reliability of each variable in the questionnaire. The researcher adapted this testing method to diagnose the reliability of the questions and calculate the data by using SPSS Program after the questionnaires were distributed to 30 respondents. The questionnaire can be assumed reliable and acceptable if the calculation results from SPSS shows that Cronbach's Alpha of each variable is greater than or equal to 0.7 (Tavakol \& Dennish, 2011).

As mentioned in Table 1, the parameter indicates that the questionnaire has reached the standards required for reliability testing, as the Cronbach's Alpha coefficients are in the range of 0.761 to 0.910 .

\section{Result and Discussion}

\subsection{Demographic Factors}

The demographic profile of the target audience of 400 respondents is summarized on Table 2 . The majority of the respondents were male, representing $56.5 \%$, whereas female respondents represented $43.5 \%$. The age brackets of the largest segment in this study (44\%) were 25-30 years old respondents; $31.25 \%$ of respondents were $31-35$ year old: $16.75 \%$ were $18-24$ year old; $6 \%$ were $36-40$ years old; and $2 \%$ were over 40 years. In terms of monthly income range of the respondents, the largest group had a monthly income THB30,001-45,000 (33\%), followed by THB15,001-30,000 (29.50\%), THB45,001-60,000 (19\%), THB60,001-75,000 $(7.75 \%)$, more than THB90,000 (5.5\%), less than THB15,000 $(2.75 \%)$, and THB75,001-90,000 (2.5\%). A majority of the respondent's occupation were private company employees $(56.75 \%)$ followed by private business $(14.5 \%)$, others $(10.25 \%)$, freelance $(8 \%)$, student/college $(6 \%)$, and government employee/state enterprises $(4.5 \%)$. For the respondents' most preferred brand, Toyota came on top with $24.25 \%$ of respondents, followed by Honda $(22.25 \%$ ), Nissan (13.25\%), Mazda (10.25\%), others (9.25\%), MG (8.5\%), BMW (7\%) and Mercedes-Benz (5.25\%).

\subsection{Confirmatory Factor Analysis (CFA)}

Confirmatory Factor Analysis (CFA) is a statistical technique that generates testing for data validation consistent with conceptual models in this study. The results of the factor loadings, the Composite Reliability (CR), and the Average Variance Extracted (AVE) can be examined by CFA, and all values should be benchmarked with the theory. Firstly, according to the theory (Kline, 1994) that the loading factor must be higher than 0.3 . The result is considered appropriate when $\mathrm{CR} \alpha>0.7$, due to the reliability was approximated by the Composite Reliability (CR) and standardized Cronbach's Alpha coefficient ( $\alpha$ ), Lastly, the Average Variance Extracted (AVE) was applied to assess the convergent validity and acceptable values of AVE $>0.5$ (Hair, Black, Babin, \& Anderson., 2010) were clarified for the factor's convergent validity as displayed in Table 3.

The testing of discriminant validity was evaluated by computing the square root of each AVE according to Fornell 
Table 1: Reliability Test (Consistency of the scales test $\mathrm{N}=30$ )

\begin{tabular}{|l|l|c|c|}
\hline \multicolumn{1}{|c|}{ Variables } & \multicolumn{1}{c|}{$\begin{array}{c}\text { Source of Questionnaire } \\
\text { (Measurement Indicator) }\end{array}$} & No. of Items & Cronbach's Alpha \\
\hline Attitude (A) & Han, Hsu, \& Sheu., (2010) & 7 & 0.761 \\
\hline Brand Preference (BP) & $\begin{array}{l}\text { Hellier et al. (2003); } \\
\text { Jamal and Al-Marri (2007); Overby \& Lee (2006) }\end{array}$ & 7 & 0.849 \\
\hline Environment Concern (EC) & Ozaki \& Sevastyanova (2011) & 3 & 0.765 \\
\hline Fuel Efficiency (FE) & Ozaki \& Sevastyanova (2011) & 3 & 0.780 \\
\hline Social Influence (SI) & Sinnappan \& Rahman (2011); Tan (2013) & 4 & 0.910 \\
\hline
\end{tabular}

Table 2: Demographic Information

\begin{tabular}{|c|c|c|c|}
\hline Demographic & Characteristics $(\mathrm{N}=400)$ & Frequency & Percentage \\
\hline Gender & $\begin{array}{l}\text { Male } \\
\text { Female }\end{array}$ & $\begin{array}{l}226 \\
174\end{array}$ & $\begin{array}{l}56.5 \% \\
43.5 \%\end{array}$ \\
\hline Age & $\begin{array}{l}18-24 \\
25-30 \\
31-35 \\
36-40 \\
\text { Above } 40\end{array}$ & $\begin{array}{c}67 \\
176 \\
125 \\
24 \\
8\end{array}$ & $\begin{array}{c}16.75 \% \\
44 \% \\
31.25 \% \\
6 \% \\
2 \%\end{array}$ \\
\hline Monthly Income & $\begin{array}{l}\text { Less than } 15,000 \\
15,001-30,000 \\
30,001-45,000 \\
45,001-60,000 \\
60,001-75,000 \\
75,001-90,000 \\
\text { More than } 90,000\end{array}$ & $\begin{array}{c}11 \\
118 \\
132 \\
76 \\
31 \\
10 \\
22\end{array}$ & $\begin{array}{c}2.75 \% \\
29.50 \% \\
33 \% \\
19 \% \\
7.75 \% \\
2.5 \% \\
5.5 \%\end{array}$ \\
\hline Occupation & $\begin{array}{l}\text { Student/College } \\
\text { Government Employees/ State Enterprises } \\
\text { Private Company Employees } \\
\text { Private Business } \\
\text { Freelancers } \\
\text { Others }\end{array}$ & $\begin{array}{c}24 \\
18 \\
227 \\
58 \\
32 \\
41\end{array}$ & $\begin{array}{c}6 \% \\
4.5 \% \\
56.75 \% \\
14.5 \% \\
8 \% \\
10.25 \%\end{array}$ \\
\hline Most Preferable Brand & $\begin{array}{l}\text { Nissan } \\
\text { MG } \\
\text { Toyota } \\
\text { Honda } \\
\text { Mazda } \\
\text { BMW } \\
\text { Mercedes-Benz } \\
\text { Others }\end{array}$ & $\begin{array}{l}53 \\
34 \\
97 \\
89 \\
41 \\
28 \\
21 \\
37\end{array}$ & $\begin{array}{c}13.25 \% \\
8.5 \% \\
24.25 \% \\
22.25 \% \\
10.25 \% \\
7 \% \\
5.25 \% \\
9.25 \%\end{array}$ \\
\hline
\end{tabular}

and Larcker (1981). In general, each variable should be greater than the covariant relation between variables in the model. From this study, the researcher identified that the correlation coefficient between two variables is smaller than the AVE square root of the structural variable. Therefore, it can be assumed that the discriminant validity is supported, as illustrated in Table 4.

According to Table 3, the confirmatory factor analysis represents an appropriate result of the six variables measurement model. On the other hand, the results of 
Table 3: Confirmatory Factor Analysis (CFA), Composite Reliability (CR), and Average Variance Extracted (AVE) Results

\begin{tabular}{|c|c|c|c|c|c|}
\hline Variables & Factor Loading & S.E. & T-Value & CR & AVE \\
\hline $\begin{array}{r}\text { Attitude (A) } \\
\text { A1 } \\
\text { A2 } \\
\text { A3 } \\
\text { A4 } \\
\text { A5 }\end{array}$ & $\begin{array}{l}0.739 \\
0.793 \\
0.682 \\
0.852 \\
0.661\end{array}$ & $\begin{array}{l}0.078 \\
0.068 \\
0.085 \\
0.073\end{array}$ & $\begin{array}{l}14.108^{\star * *} \\
14.956^{\star * *} \\
13.653^{\star * *} \\
12.086^{\star * *}\end{array}$ & 0.863 & 0.561 \\
\hline $\begin{array}{c}\text { Brand Preference (BP) } \\
\text { BP1 } \\
\text { BP2 } \\
\text { BP6 } \\
\text { BP7 }\end{array}$ & $\begin{array}{l}0.627 \\
0.718 \\
0.847 \\
0.822\end{array}$ & $\begin{array}{l}0.079 \\
0.097 \\
0.095\end{array}$ & $\begin{array}{l}13.796^{* * *} \\
13.420^{* * *} \\
13.102^{\star * *}\end{array}$ & 0.842 & 0.575 \\
\hline $\begin{array}{l}\text { Environment Concern (EC) } \\
\text { EC1 } \\
\text { EC2 } \\
\text { EC3 }\end{array}$ & $\begin{array}{l}0.830 \\
0.907 \\
0.864\end{array}$ & $\begin{array}{l}0.050 \\
0.050\end{array}$ & $\begin{array}{l}22.669^{* * *} \\
21.210^{* \star *}\end{array}$ & 0.901 & 0.753 \\
\hline $\begin{array}{l}\text { Fuel Efficiency (FE) } \\
\text { FE1 } \\
\text { FE2 } \\
\text { FE3 }\end{array}$ & $\begin{array}{l}0.848 \\
0.912 \\
0.859\end{array}$ & $\begin{array}{l}0.042 \\
0.043\end{array}$ & $\begin{array}{l}24.499^{\star * *} \\
22.053^{\star * *}\end{array}$ & 0.906 & 0.763 \\
\hline $\begin{array}{c}\text { Social Influence (SI) } \\
\text { SI1 } \\
\text { SI2 } \\
\text { SI3 } \\
\text { SI4 }\end{array}$ & $\begin{array}{l}0.768 \\
0.794 \\
0.866 \\
0.870\end{array}$ & $\begin{array}{l}0.043 \\
0.062 \\
0.063\end{array}$ & $\begin{array}{l}23.827^{* * *} \\
18.301^{* * *} \\
18.479^{* * *}\end{array}$ & 0.895 & 0.682 \\
\hline
\end{tabular}

Table 4: Discriminant Validity

\begin{tabular}{|c|c|c|c|c|c|}
\hline & A & BP & EC & FE & SI \\
\hline A & 0.748 & & & & \\
\hline BP & 0.505 & 0.759 & & & \\
\hline EC & 0.497 & 0.744 & 0.868 & & \\
\hline FE & 0.476 & 0.723 & 0.700 & 0.873 & \\
\hline SI & 0.532 & 0.667 & 0.632 & 0.784 & 0.826 \\
\hline \multicolumn{6}{l}{ The diagonally listed values are the AVE square roots of the variables } \\
\hline
\end{tabular}

all indices were above the given values in Table 5, which indicates that the hypotheses of this research have proper suitability for this research.

\subsection{Structural Equation Model (SEM)}

Structural Equation Modeling is a Multivariate statistical concept that verifies the relation between constructs in a model and also covers measurement falsity in the structure coefficient (Hair et al., 2010; MacKenzie, 2001). Subsequent of the process in SEMs and adjusting the model, the results showed that the overall model fit index is $\mathrm{CMIN} / \mathrm{DF}=2.099, \mathrm{GFI}=0.947, \mathrm{AGFI}=0.905, \mathrm{NFI}=$ $0.966, \mathrm{CFI}=0.982, \mathrm{TLI}=0.970, \mathrm{RMSEA}=0.052, \mathrm{RMR}=$ 0.032 , according to the measurable criteria that mentioned in Table 6. 
Table 5: Goodness of Fit

\begin{tabular}{|c|c|c|}
\hline Goodness-of-Fit Indices & Criterion & Results of this Study \\
\hline Chi-Square (CMIN) & $<3.00$ (Hair, Black, Babin, Anderson, \& Tatham, 2006) & 2.099 \\
\hline Goodness-of-Fit Index (GFI) & > 0.90 (Miles \& Shevlin, 1998) & 0.947 \\
\hline Adjusted Goodness of Fit Index (AGFI) & > 0.90 (Hooper, Coughlan, \& Mullen, 2008). & 0.905 \\
\hline Normed Fit Index (NFI) & > 0.90 (Bentler \& Bonnet, 1980) & 0.966 \\
\hline Comparative Fit Index (CFI) & > 0.90 (Bentler, 1990) & 0.982 \\
\hline Turker Lewis Index (TLI) & > 0.90 (Bentler \& Bonett, 1980) & 0.970 \\
\hline $\begin{array}{l}\text { Root Mean Square Error of } \\
\text { Approximation (RMSEA) }\end{array}$ & < 0.08 (MacCallum, Browne, \& Sugawara., 1996) & 0.052 \\
\hline Root Mean Square Residual (RMR) & $<0.05$ (Hair et al., 2006) & 0.032 \\
\hline \multicolumn{3}{|c|}{ CMIN/DF = The ratio of the chi-square value to degree of freedom, GFI = goodness-of-fit index, } \\
\hline \multicolumn{3}{|c|}{$\begin{array}{l}\mathrm{AGFI}=\text { adjusted goodness-of-fit index, } \mathrm{NFI}=\text { normalized fit index, } \mathrm{TLI}=\text { Tucker-Lewis index, } \mathrm{CFI}=\text { comparative fit index, RMSEA = root } \\
\text { mean square error of approximation, and RMR = rootmean square residual }\end{array}$} \\
\hline
\end{tabular}

\subsection{Research Hypothesis Testing}

The results of hypotheses testing show that $\mathrm{H}_{1}, \mathrm{H}_{2}, \mathrm{H}_{3}$, $\mathrm{H}_{4}, \mathrm{H}_{5}$ and $\mathrm{H}_{6}$ are supported.

$\mathbf{H}_{\mathbf{1}}$ : The standardized path coefficient between Social influence and Environment concern was 0.753 (t-value $\left.=14.551^{* * *}\right)$. Social influence has significant effect on environment concern. Thus, $\mathrm{H}_{1}$ was supported. Social influence is a process of change, both feelings and actions that can occur unconsciously and will affect the customer including the influence of society and environmental concerns on the behavior of using environmental friendly products. The values from SEM shows that consumers are most likely to be influenced by the advices received from their family (0.879) and recommendation from their friends (0.860). Therefore, environmental concern values by their closed ones are prominent to influence consumers' values and green purchasing behavior for products or brands that are more environmental friendly. This set of findings are aligned with the past researches of Dagher and Itani (2012) and Khare (2015).

$\mathbf{H}_{2}$ : The standardized path coefficient between social influence and attitude was 0.707 ( $\mathrm{t}$-value $\left.=10.104^{* * *}\right)$. Social influence has significant effect on attitude. Thus, $\mathrm{H}_{2}$ was supported. The results of this study correspond to previous studies conducted by Rivis and Sheeran (2003), Hsu and $\mathrm{Lu}$ (2004), Rashotte (2007), Bartikowski and Walsh (2014), and Khare (2014). It can predicate that social influence, in the sense of influences from family, friends or close people, affects personal attitudes while deciding to do things that includes attitude toward products or brands. Positive recommendation or persuasion received from consumers' family $(0.879)$ and friends $(0.860)$ would affect favorable attitudes toward environment-friendly products, or vice versa.

$\mathbf{H}_{3}$ : The standardized path coefficient between environment concern and fuel efficiency was 0.379 ( $t$-value $\left.=6.551^{* * *}\right)$. Environment concern has significant effect on fuel efficiency. Thus, $\mathrm{H}_{3}$ was supported. It can describe that those having environmental awareness will consider products that less harm the environment. The environmental concerns on electric vehicle for the responded consumers are ranked from preserving the environment (0.909), pollution level (0.859), then effect of climate change (0.829). Therefore, environmental conscious consumers would consider fuel efficiency as one of the factors when considering brand preference for electric vehicles. The better fuel efficiency, the lesser harm and better preservation of environment. This result is also supported by previous studies conducted by Kwon et al. (2016).

$\mathbf{H}_{4}$ : The standardized path coefficient between environment concern and brand preference was 0.478 $(\mathrm{t}$-value $=6.984 * * *)$. Environment concern has significant effect on brand preference. Thus, $\mathrm{H}_{4}$ was supported. The finding reinforces the concept from the study of Junior et al. (2014) and Teoh and Gaur (2019). It can be inferred that environmental concern can increase brand satisfaction through environment-friendly products offered.

$\mathbf{H}_{5}$ : The standardized path coefficient between fuel efficiency and brand preference was 0.431 (t-value = $\left.6.303^{* * *}\right)$. Fuel efficiency has significant effect on brand preference. Thus, $\mathrm{H}_{5}$ was supported. It can conclude that the brand preference of consumer will increase according to product characteristics, especially the fuel efficiency in electric vehicles. Fuel efficiency defined by the consumers is economical driving (0.923) and consumes less petrol (0.853). 
Thus, the brand that provides better economical driving is more likely to be preferred by the consumers. This result is in line with previous research by Park and Srinivasan (1994), Cobb-Walgren et al. (1995), Myers (2003) and Chowdhury, Salam and Tay (2016).

$\mathbf{H}_{6}$ : The standardized path coefficient between attitude and brand preference was 0.097 (t-value $=2.350 *$ ). Attitude has significant effect on brand preference. Thus, $\mathrm{H}_{6}$ was supported. The results illustrate similarities with the idea from previous research conducted by Huang, Yang and Wang (2014) and Hsu et al. (2017). It can be assumed that the attitude of consumers toward environment-friendly products affects the selection of brand preference, which largely depends on individual opinion. Positive attitude toward environment-friendly products in the subject of electric vehicle can be enhanced if the consumer perceived the vehicle as desirable (0.841) and favorable (0.828).

\subsection{Direct, Indirect and Total Effects of Relationships}

The analysis on the relationship structure between the variables is conducted by using AMOS program in order to explain the direct, indirect and total effects of variables. The direct effect refers to the relationship between two variables without mediating variables to measure in the model. Whereas, an indirect effect consists of the relationship between two variables and mediated at least by one mediating variable (Raykov \& Marcoulides, 2000). The direct, indirect and total effect of relationships are explained in details below.

\subsubsection{Attitude}

The significant direct effect of social influence on attitude was 0.707 . There was no profound indirect effect. Therefore, the total effects were equal to 0.707 . In terms of total effect, social influence is an important variable that significantly affects attitude.

\subsubsection{Environment Concern}

The significant direct effect of social influence on environment concern was 0.753 . There was no profound indirect effect. Therefore, the direct effects were equal to 0.753. In terms of the total effect, social influence is an important variable that significantly affects environment concern.

\subsubsection{Fuel Efficiency}

The significant direct effect of environment concern on fuel efficiency was 0.379 and there were some indirect effects that the significant indirect effect of social influence on fuel efficiency was identified at 0.285 . In term of the total effect, environment concern is the most important variable that significantly affects fuel efficiency followed by social influence on fuel efficiency as shown in Table 8.

\subsubsection{Brand Preference}

There are three variables that directly affect brand preference. First, a significant direct effect of attitude on brand preference was 0.097 . Next, the significant direct effect of fuel efficiency on brand preference was 0.431 . Lastly, the significant direct effect of environment concern on brand preference was 0.478 . Whereas there were some indirect effects, the significant indirect effect of environment concern on brand preference was 0.163 and the significant indirect effect of social influence on brand preference was 0.552 , as shown in the table.

To summarize, social influence has the most significant effect on environment concern (0.753) and affects attitude (0.707) followed by an environment concern on brand preference (0.478), the fuel efficiency on brand preference (0.431), the environment concern on fuel efficiency (0.379), and attitude on brand preference (0.097).

\section{Conclusion, Recommendation and Limitation}

\subsection{Conclusion}

In this study, the research has expanded the current literature by understanding and investigating brand preference. This research aims to study the factors that affect consumers' brand preference toward environmentallyfriendly products such as electric vehicles in Bangkok, Thailand, since its launch in 2009. A total of 400 questionnaires were distributed in Bangkok to Thais older than 18 years old who has knowledge of electric vehicles. The conceptual framework was applied from theory and statistics, which consisted of social influence, environment concern, fuel efficiency, attitude and brand preference for examining all hypotheses. The outcome of this research was validated to ensure reliability by Confirmatory Factor Analysis (CFA) and the Structural Equation Model (SEM) that were used to verify the influence of measuring variables and construct a conclusion of this study.

The research describes all factors affecting brand preference. When ranked by its effect significance, it would begins with environment concern, fuel efficiency and attitude, which significantly affect brand preference towards environment-friendly products such as electric vehicle consistent with existing studies (Junior et al., 2014; Hensher et al., 2011; McCarthy \& Tay, 1989, 1991, 1998; Train \& 
Winston, 2007; Cobb-Walgren et al., 1995; Myers, 2003; Park \& Srinivasan, 1994; Hsu et al., 2017).

The findings of this research show that environmentallyconscious consumers would highly consider the electric vehicle functions and features that would preserve the environment, generate less $\mathrm{CO} 2$ emission (environment concern) and economical driving (fuel efficiency). Apart from consumers' environment concern, attitude is another crucial factor that affects consumers' brand preference. A positive attitude towards environment-friendly products such as electric vehicles is mainly driven by persuasion from their family and friends (social influence) and other aspects of psychological response to beauty, convenience, including car functionality. Personal norms for the brand and social influence, are key elements that affect a person's attitude and intentions toward certain behaviors (Rivis \& Sheeran, 2003; Hsu \& Lu, 2004). It is obvious that human attitudes and social influence both are important for brand preference, even if they have indirect implications. Therefore, any electric vehicle brand that is able to moderate the highlighted environment concerns and got recommended from consumers' closed ones would be more preferred over the competitors.

\subsection{Recommendations}

The result of this research indicates factors that brands should consider to impress and receive recognition from consumers. The crucial factors are moderating environment concerns of environmentally-conscious consumers and building favorable attitudes toward environment-friendly electric vehicles, including the fuel efficiency that is economical and consumes less petrol. Social influence is a significant factor to persuade environment concerns and build positive attitudes.

Therefore, this research provides recommendations that brands should be involved with social influencer marketing, such as sponsoring cars to influencers who have numerous followers and huge credibility for test drive and let them review along with promoting brands in their channels. The key message of this promotion should be to emphasize the eco-friendliness (environment concern), performance efficiency (fuel efficiency), and why to create desirable (attitudes) is needed. This would provide product knowledge and create consumers' trust through social influence. Also, sponsoring mainstream media such as television series helps viewers to see and build brand awareness.

In addition, the brands should be continually improved to create or maintain competitive advantage over the competitors in terms of economical and efficient performance of electric vehicle. This can be done by developing or innovating technologies that respond to the evolving nature and environmental concerns and scarcity.

\subsection{Limitation and Further Study}

This study has certain limitations that should be explored in further research. Firstly, the data covers only the automotive industry, specifically green vehicles. Moreover, given the low usage rate of electric vehicles, it is difficult for real users to participate in this study. For this reason, future research should focus on expanding the study and focus on existing electric vehicles users to study how brand experience affects brand preference. This will help answer whether the brand preference leads to purchase intention or not by coordinating with more respondents in diverse geographical areas.

In addition, future research should include qualitative surveys such as interviews or focus groups for more reliable and quality data, as electric vehicles tend to be more popular in future. Therefore, research should expand the scope of purchase intention because brand preference would be reflected in purchase intention (Chang \& Liu, 2009). Further study can be extended to identify factors that influence purchase intention and factors from brand reference that allow brand owners and marketers to fully understand the way customers consume products. However, factors to be considered should change or being prioritized, such as trust or brand loyalty, for a more comprehensive research.

\section{References}

Bartikowski, B., \& Walsh, G. (2014), Attitude contagion in consumer opinion platforms: posters and lurkers, Electronic Markets, 24(3), 207-217.

Bentler, P. M., \& Bonnet, D. C. (1980). Significance tests and goodness of fit in the analysis of covariance structures. Psychological Bulletin, 88(3), 588-606.

Bentler, P. M. (1990). Comparative fit indexes in structural models. Psychological bulletin, 107(2), 238.

Chang, H. H., \& Liu, Y. M. (2009). The impact of brand equity on brand preference and purchase intention in the service industries. The Service Industries Journal, 29(12), 1687-1706.

Chowdhury, M., Salam, K. \& Tay, R. (2016). Consumer preferences and policy implications for the green car market. Marketing Intelligence \& Planning, 34(6), 810-827.

Cobb-Walgren, C. J., Ruble, C. A., \& Donthu, N. (1995). Brand equity, brand preference, and purchase intent. Journal of Advertising, 24(3), 25-40.

Dagher, G., \& Itani, O. (2012). The influence of environmental attitude, environmental concern and social influence on green purchasing behavior. Review of Business Research, 12(2), 104111 .

Dao, B. T. T., \& Nguyen, D. P. (2020). Determinants of profitability in commercial banks in Vietnam, Malaysia and Thailand. Journal of Asian Finance, Economics and Business, 7(4), 133143. DOI: 10.13106/jafeb.2020.vol7.no4.133 
Dnishev, F., \& Alzhanova, F. (2016). Globalization of technological development and opportunities for national innovation systems of developing countries. Journal of Asian Finance, Economics and Business, 3(4), 67-79. DOI: 10.13106/jafeb.2016.vol3. no4.67.

Ebrahim, R., Ghoneim, A., Irani, Z., \& Fan, Y. (2016). A brand preference and repurchase intention model: the role of consumer experience, Journal of Marketing Management, 32(13-14), 1230-1259.

Energy Policy and Planning Office (2016). Thailand 20-Year Energy Efficiency Development Plan (2011-2030). Ministry of Energy. Retrieved May 20, 2020, from: http://www.eppo.go.th.

Fishbein, M., \& Ajzen, I. (1975). Belief, Attitude, Intention and Behavior: An Introduction to Theory and Research. Reading, MA: Addison-Wesley.

Fornell, C., \& Larcker, D. F. (1981). Evaluating structural equation models with unobservable variables a measurement error. Journal of Marketing Research, 18, 39-50.

Gaur, A. S., \& Kumar, M. (2018). A systematic approach to conducting review studies: an assessment of content analysis in 25 years of IB research. Journal of World Business, 53(2), 280-289.

Hair, J., Black, W., Babin, B., Anderson, R., \& Tatham, R. (2006). Multivariate Data Analysis (6th ed.). Harlow, UK: Pearson Education.

Hair, J., Black, W., Babin, B., \& Anderson, R. (2010). Multivariate Data Analysis (7th ed.). Upper Saddle River, NJ: Prentice Hall.

Han, H., Hsu, L. T. J., \& Sheu, C. (2010). Application of the theory of planned behavior to green hotel choice: testing the effect of environmental friendly activities, Tourism Management, 31(3), 325-334.

Heilman, C. M., Bowman, D., \& Wright, G. P. (2000). The evolution of brand preferences and choice behaviors of consumers new to a market. Journal of Marketing Research, 37(2), 139-155.

Hellier, P. K., Geursen, G. M., Carr, R. A., \& Rickard, J. A. (2003). Customer repurchase intention: a general structural equation model. European Journal of Marketing, 37(11-12), 1762-1800.

Hensher, D. A., Greene, W. H., \& Li, Z. (2011). Embedding risk attitude and decision weights in non-linear logit to accommodate time variability in the value of expected travel time savings. Transportation Research Part B: Methodological, 45(7), 954972.

Hoek, G., Krishnan, R. M., Beelen, R., Peters, A., Ostro, B., Brunekreef, B., \& Kaufman, J. D. (2013). Long-term air pollution exposure and cardio-respiratory mortality: A review. Environmental Health: A Global Access Science Source. 12, Article number: 43(2013). https://doi.org/10.1186/1476069X-12-43.

Hooper, D., Coughlan, J., \& Mullen, M. (2008). Structural equation modelling: guidelines for determining model fit. Electronic Journal of Business Research Methods, 6(1), 53-60.
Hsu, C. L., \& Lu, H. P. (2004). Why do people play online games? An extended TAM with social influences and flow experience. Information and Management, 41(7), 853-868.

Hsu, C., Chang, C., \& Yansritakul, C. (2017). Exploring purchase intention of green skincare products using the theory of planned behavior: testing the moderating effects of country of origin and price sensitivity. Journal of Retailing and Consumer Services, 34, 145-152. DOI: 10.1016/j.jretconser.2016.10.006.

Huang, Y. C., Yang, M., \& Wang, Y. C. (2014). Effects of green brand on green purchase intention. Marketing Intelligence and Planning, 32(3), 250-268.

International Transport Forum (2011). Statistics Record of Thailand $\mathrm{CO}_{2}$ Emission. Retrieved April 17, 2020, from: http://www. internationaltransportforum.org/.

Jamal, A., \& Al-Marri, M. (2007). Exploring the effect of selfimage congruence and brand preference on satisfaction: the role of expertise. Journal of Marketing Management, 23(7-8), 613-629.

Junior, B. S. S., da Silva, D., Satolo, E. G., Magalhães, M. M., Putti, F. F., \& de Braga, O. W. R. (2014). Environmental concern has to do with the stated purchase behavior of green products at retail?. Social Sciences, 3(1), 23-30. DOI: 10.11648/j. ss.20140301.15.

Khare, A. (2014). Consumers' susceptibility to interpersonal influence as a determining factor of ecologically conscious behavior. Marketing Intelligence \& Planning, 32(1), 2-20.

Khare, A. (2015). Antecedents to green buying behavior: a study on consumers in an emerging economy. Marketing Intelligence \& Planning, 33(3), 309-329.

Kline, P. (1994). An easy guide to factor analysis. New York, NY: Routledge.

Kline, R. B. (2011). Principles and practice of structural equation modeling (3rd ed.). New York, NY: The Guilford Press.

Kwon, W., Engils, B., \& Mann, M. (2016). Are third-party greenbrown ratings believed?: The role of prior brand loyalty and environmental concern. Journal of Business Research, 69(2), 815-822.

Lorenzoni, I., \& Pidgeon, N. F. (2006). Public views on climate change: European and USA perspectives. Climatic Change, 77, 73-95. DOI: 10.1007/s10584-006-9072-z.

MacCallum, R. C., Browne, M. W., \& Sugawara, H. M. (1996). Power analysis and determination of sample size for covariance structure modelling. Psychological Methods, 1(2), 130-49.

MacKenzie, S. (2001). Opportunities for improving consumer research through latent variable structural equation modeling. Journal of Consumer Research, 28, 159-166.

McCarthy, P., \& Tay, R. (1998). A nested logit model of vehicle demand with implications for fuel efficiency. Transportation Research Part E: Logistics and Transportation Review, 34(1), 9-51. 
Miles, J., \& Shevlin, M. (1998). Effects of sample size, model specification and factor loadings on the GFI in confirmatory factor analysis. Personality and Individual Differences, 25, 8590 .

Myers, C. A. (2003). Managing brand equity: A look at the impact of attributes. Journal of Product \& Brand Management, 12(1), 39-51. DOI: 10.1108/10610420310463126.

National Automobile Dealers Association. (2014). New car shopper preference survey. Retrieved May 12, 2020, from: http://automotivedigest.com/.

Oh, A., \& Park, H. (2020). The effects of airlines' professional models on brand loyalty: focusing on mediating effect of brand attitude. Journal of Asian Finance, Economics and Business, 7(5), 155-166. DOI: 10.13106/jafeb.2020.vol7.no5.155.

Overby, J. W., \& Lee, E. J. (2006). The effects of utilitarian and hedonic online shopping value on consumer preference and intentions. Journal of Business Research, 59(10-11), 11601166.

Ozaki, R., \& Sevastyanova, K. (2011). Going hybrid: an analysis of consumer purchase motivations. Energy Policy, 39(5), 22172227.

Park, C. S., \& Srinivasan, V. (1994). A survey-based method for measuring and understanding brand equity and its extendibility. Journal of Marketing Research, 31(2), 271-288. DOI: $10.2307 / 3152199$

Parry, I. W. H., Walls, M., \& Harrington, W. (2007). Automobile Externalities and Policies. Journal of Economic Literature, 45, 373-399.

Rashotte, L. S. (2007). Social influence, in Ritzer, G. \& Ryan, J. M. (Eds)., The Blackwell Encyclopedia of Sociology (pp. 44264429). Malden, MA: Blackwell Publishing.

Raykov, T., \& Marcoulides, G. A. (2000). A first course in structural equation modeling. Mahwah, NJ: Erlbaum.

Rivis, A., \& Sheeran, P. (2003). Social influences and the theory of planned behavior: evidence for a direct relationship between prototypes and young people's exercise behavior. Psychology and Health, 18(5), 567-583.

Sinnappan, P., \& Rahman, A. A. (2011). Antecedents of green purchasing behavior among Malaysian consumers. International Business Management, 5(3), 129-139.

Smith, J. R., \& Hogg, M. A. (2008). Social identity and attitudes, in Crano, W. D., \& Prisin, R. (Eds), Attitudes and Attitude Change (pp. 337-360). New York, NY: Taylor \& Francis Group,.

Tan, T. H. (2013). Use of structural equation modeling to predict the intention to purchase green and sustainable homes in Malaysia. Asian Social Science, 9(10), 181-191.

Tavakol, M., \& Dennick, R. (2011). Making sense of Cronbach's alpha. International Journal of Medical Education, 2, 53-55. doi: $10.5116 /$ ijme.4dfb.8dfd

Tay, R. S. \& McCarthy, P. (1991). Demand Oriented Policy for Improving Market Share in the US Automobile Market. International Journal of Transport Economic, 18, 151-66.

Teoh, C., \& Gaur, S. (2019). Environmental concern: an issue for poor or rich. Management of Environmental, Quality: An International Journal, 30(1), 227-242.

Train, K., \& Winston, C. (2007). Vehicle choice behavior and the declining market share of U.S. automakers. International Economic Review, 48, 1469-149.

UNFCCC (2015, November 29). Paris Declaration on ElectroMobility and Climate Change \& Call to Action. Retrieved April 18, 2020, from: https://unfecc.int.

Woodcock, J. W., Edwards, P., Tonne, C., Armstrong, B. G., Ashiru, O., Banister, D., Beevers, S., Chalabi, Z., Chowdhury, Z., Cohen, A., Franco, O. H., Haines, A., Hickman, R., Lindsay, G., Mittal, I., Mohan, D., Tiwari, G., Woodward, A., \& Roberts, I. (2009). Public health benefits of strategies to reduce greenhouse-gas emissions: urban land transport. The Lancet, 374, 19301943. DOI: 10.1016/S0140-6736(09)61714-1. 